\title{
HANDS-ON PENGUJIAN DAN EVALUASI SISTEM KOLIMATOR SEBAGAI UPAYA KESELAMATAN RADIASI RADIOLOGI
}

\author{
Yeti Kartikasari*)1, Dwi Rochmayanti², Siti Masrochah³, M. Irwan Katili ${ }^{4}$ \\ 1, 2, 3,4 Jurusan Teknik Radiodiagnostik dan Radioterapi ; Poltekkes Kemenkes Semarang \\ Jl. Tirto Agung ; Pedalangan ; Banyumanik; Semarang
}

\begin{abstract}
Abstrak
Pengujian kolimator merupakan factor yang cukup penting dan menjadi salah satu dalam parameter pengujian pesawat sinar $\mathrm{X}$ utnuk mendapatkan perijinan dari bapeten. Akan tetapi dilapangan, hal ini menjadi sedikit terabaikan karena tidak berhubungan secara langsung dengan produksi sinar-X, oleh karena itu dilakukan kegiatan pengabdian masyarakat dalam bentuk pelatihan dan pendampingan pengujian sistem kolimator. Kegiatan ini bertujuan Untuk memberikan pelatihan bagi radiografer dalam memastikan kinerja sistem kolimator pada pesawat sinar X, dalam rangka upaya keselamatan radiasi pada unit pelayanan radiologi Rumah Sakit di Kota Semarang. Sasaran kegiatan ini adalah radiografer di Instalasi Radiologi pada Rumah Sakit di Kota Semarang. Kegiatan dikemas dalam bentuk kegiatan pelatihan dan pendampingan yang memungkinkan para peserta mempraktekan secara langsung, sehingga materi pengabmas diharapkan dapat lebih dipahami dan diterapkan di masing-masing pesawat radiologi oleh para peserta. Materi pelatihan meliputi penjelasan mengenai quality assurance dari pesawat sinar- $X$, khususnya system kolimator dan dilanjutkan dengan praktek pengujian secara langsung. Hasil akhir pengabmas adalah berupa buku petunjuk pengujian. Sebagai bentuk tindak lanjut dilakukan pendampingan bagi peserta untuk melakukan di tempat masing-masingsebagai bentuk dari upaya keselamatan radiasi.
\end{abstract}

Kata kunci: Hands-on, sistem kolimator, keselamatan radiasi

\begin{abstract}
[HANDS-ON TESTING AND EVALUATION OF COLLIMATOR SYSTEMS AS A RADIOLOGICAL RADIATION SAFETY] Collimator testing is a fairly important factor for testing $X$-ray aircraft to obtain a permit from Bapeten. However, in the field, this has become a bit neglected because it is not directly related to X-ray production, therefore community service activities are carried out in the form of training and assistance for testing collimator systems. This activity aims to provide training for radiographers in ensuring the performance of the collimator system on X-ray aircraft, in the context of radiation safety efforts at the radiology service unit of the Hospital in Semarang City. The target of this activity is the radiographer at the Radiology Department. The activities are packaged in the form of training and mentoring activities that allow participants to practice directly, so that the community service material is expected to be better understood and applied in each radiology. The training material an explanation of the quality assurance of X-ray aircraft, especially the collimator system and is followed by hands-on testing practices. The final result of the community service is in the form of a test manual. As a form of follow-up, assistance was provided for participants to do it in their respective places as a form of radiation safety efforts.
\end{abstract}

Keywords: Hands-on, collimator system, radiation safety

\section{Pendahuluan}

Naskah Jaminan mutu atau Quality Assurance (QA) adalah keseluruhan dari program

\footnotetext{
*) Correspondence Author (Yeti Kartikasari)

E-mail: yeti.kartikasari@gmail.com
}

manajemen (pengelolaan) yang diselenggarakan guna menjamin pelayanan kesehatan prima dengan cara pengumpulan data dan melakukan evaluasi secara sistematis. Aplikasi dari jaminan mutu tersebut diwujudkan pada program kendali mutu atau Quality Control (QC) (Papp 2015). 
Kendali mutu atau Quality Control (QC) menitikberatkan aktifitas programnya pada teknik-teknik yang diperlukan bagi pengawasan, perawatan dan menjaga elemen-elemen teknis dari suatu sistem peralatan radiografi dan citra yang mempengaruhi mutu gambar. Kendali mutu yang dapat dilakukan pada pesawat sinar$\mathrm{X}$ terdiri dari akurasi tegangan tabung $(\mathrm{kVp})$, akurasi linearitas keluaran (mA), akurasi waktu (s), kebocoran tabung, ukuran focal spot, filtrasi, dan kesesuaian luas lapangan kolimator dan arah berkas sinar-X (Bushong 2016). Quality Control merupakan bagian program Quality Assurance yang berhubungan dengan bagian-bagian teknis dalam mempengaruhi kualitas gambar. Hal ini berperan dalam mengendalikan output untuk menghasilkan kualitas gambar yang baik (Dwi Rochmayanti, Tiara Pratiwi Putri 2017)

Salah satu uji kesesuaian pada pesawat sinar-X dilakukan pada pembatas luas lapangan berkas sinar-X atau kolimator (BAPETEN 2018). Kolimator merupakan jenis pembatas yang mempunyai bentuk seperti bujur sangkar. Kolimator ini sangat bermanfaat dalam pengaturan luas lapangan yang identik dengan luas lapangan berkas sinar- $X$ dan dapat menunjukkan pertengahan luas lapangan secara tepat dengan bantuan lampu.

Meskipun kolimator sudah di desain sebaik mungkin, tak jarang pula kolimator mengalami gangguan seperti matinya lampu kolimator, macetnya shutter kolimator, penyudutan arah sinar, dan ketidaksesuaian luas lapangan kolimator dengan berkas sinar-X. Gangguan yang lebih sering terjadi pada kolimator adalah ketidaksesuaian luas lapangan kolimator dengan berkas sinar-X yang dapat disebabkan oleh sudut kemiringan cermin yang tidak tepat (Carlton, R. R., \& Adler 2013)

Kendali mutu ini di instalasi radiologi masih kurang diperhatikan oleh personel yang bertanggung jawab, yakni Radiografer. Hal menjadi kendala utama adalah keterbatasan alat dan pengetahuan. Sesuai Keputusan Menteri Kesehatan diperlukan suatu pengujian terhadap pesawat sinar-X salah satunya adalah pengujian kolimator (Kemenkes 2009)

Kolimator ini sangat bermanfaat dalam pengaturan luas lapangan yang identik dengan luas lapangan berkas sinar-X dan dapat menunjukkan pertengahan luas lapangan secara tepat dengan bantuan lampu (Sari ayu wita 2017). Permasalahan pada penggunaan pesawat sinar- $X$ adalah Penyimpangan iluminasi, Penyimpangan lapangan kolimasi dengan berkas radiasi, Penyimpangan ketegaklurusan berkas radiasi, ketidaktepatan kolimator terhadap luas lapang berkas sinar-X. (Hotromasari 2018).

Oleh karena itu kami jadikan hal ini sebagai fokus pengabmas, yakni hands-on pengujian dan evaluasi hasil pengujian collimator sebagai upaya keselamatan radiasi pada unit pelayanan radiologi rumah sakit di kota Semarang, orientasi nya adalah dengan melalukan pengujian dengan alat sederhana yang memungkinkan bisa digunakan sebagai alternative pengujian system kolimasi.

\section{Metode}

Kegiatan pengabmas ini didisain dalam kegiatan: persiapan administrative, hands-on prosedur pengujian kolimator; Pelaporan dan Tindak Lanjut. Out-put adalah buku petunjuk praktek uji kolimator dan peningkatan pengetahuan dan skill/ ketrampilan partisipan menerapkan dan melakukan prosedur pengujian kolimator sebagai jaminan mutu secara tepat; penyajian pelaporan dan menentukan tindak lanjut solusi pemecahan masalah. Adapun alur kegiatan dapat dilihat pada gambar 1 .

Metode pendekatan pembelajaran yang dipakai dalam pelatihan terstruktur ini adalah ceramah, diskusi-demonstrasi menggunakan video, dan praktik pengujian. Praktik pengujian dilakukan di RS Roemani Semarang. Pada Saat Praktikum Peserta melakukan 5 uji fungsi dari kolimator meliputi: Fungsi Timer Kolimator; Fungsi Iluminasi Lampu kolimator; Fungsi Indikator Panjang dan Lebar dari bukaan Kolimasi; Fungsi ukuran kolimasi/beam aligment dan Central point; serta uji fungsi kolimator terkait kebocoran kolimator. Alat terstandar yang digunakan sebagai referensi adalah beam alignment test tool (Gammex 2003)

Pendampingan kegiatan juga dilakukan supaya penguatan implementasi pengujian di tempat kerja masing-masing. Kegiatan ini bekerjasama dengan PARI Pengcab kota Semarang, khususnya dalam hal fasilitasi tempat kegiatan praktek pengujian dan mengidentifikasi peserta pengabmas. 


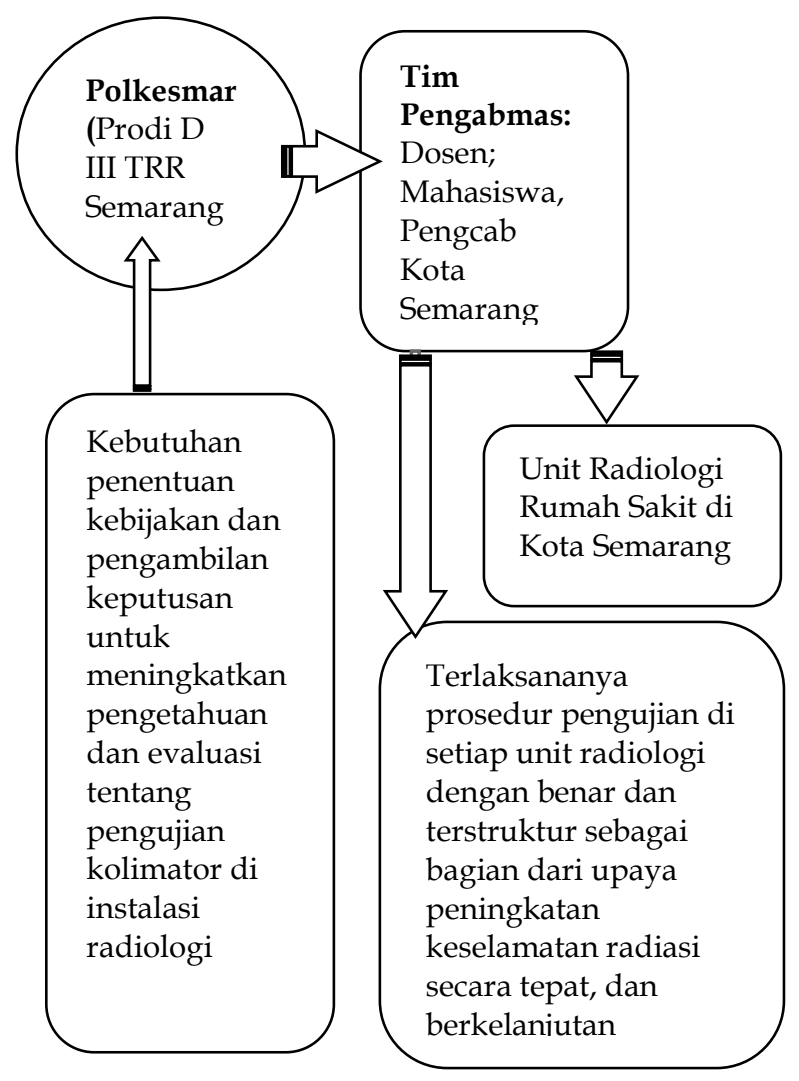

Gambar 1. Alur kegiatan Pengabmas

\section{Hasil dan Pembahasan}

Pengabmas Program prosedur pengujian sistem kolimator dan evaluasinya dari jaminan mutu pada pesawat Radiologi guna mendukung jaminan keselamatan radiasi Pada Unit Pelayanan Radiologi Rumah Sakit di Kota Semarang dilakukan berkoordinasi dengan Pengurus PARI cabang Kota Semarang. Tim Pengabmas dari Prodi D-III Teknik Radiodiagnostik dan Radioterapi Semarang Jurusan Teknik Radiodiagnostik dan Radioterapi membuat buku petunjuk pengujian kolimator secara sederhana, selain membuat buku petunjuk praktek pengujian kolimator, Tim Pengabmas juga membuat Video yang berisi Simulasi dari Pengujian Sistem Kolimator.

Pelaksanaan Kegiatan Pengabmas dilakukan pada di RS Roemani Muhammadiyah Semarang. Kegiatan meliputi registrasi peserta, pre-tes, pembukaan, penyajian materi dan dilanjutkan dengan kegiatan praktek di Radiologi RS Roemani. Kegiatan praktek dilakukan dengan pembagian kelompok, dimana setiap kelompok di dampingi oleh dosen dan tim mahasiswa. Praktek meliputi lima pengujian kolimator secara sederhana. Pengujian dilakukan di dua Pesawat Sinar-X yang ada di RS Roemani. Selanjutnya dilakukan Evaluasi hasil pengujian dan post-tes tentang pengujian kolimator. Hasil pre-test ratarata 31,94 dan nilai rata-rata post-test 69,60 . Ini menunjukkan kenaikan posentase $84,79 \%$.

Adapun evaluasi kegiatan menyatakan bahwa 96, $7 \%$ menyatakan kegiatan berguna di tempat kerja; pemberian materi $60 \%$ sangat jelas, $40 \%$ cukup jelas; posedur praktek 96,7 mudah dilakukan, $100 \%$ menyatakan bahwa prosedur uji bisa diaplikasikan di radiologi masing-masing, 86,7 komitmen untuk melakukan di rumah sakit/klinik tempat kerja, $100 \%$ menyatakan kesediaan untuk dilakukan pendampingan.

Sebagai tindak lanjut kegiatan pengabmas, dilakukan pendampingan dan pengujian mandiri di tempat kerja masing-masing dan mengirimkan hasilnya kepada tim Pengabmas. Peserta melakukan 5 uji fungsi dari kolimator meliputi: Fungsi Timer Kolimator; Fungsi Iluminasi Lampu kolimator; Fungsi Indikator Panjang dan Lebar dari bukaan Kolimasi; Fungsi ukuran kolimasi/beam aligment dan Central point; serta fungsi kebocoran kolimator.

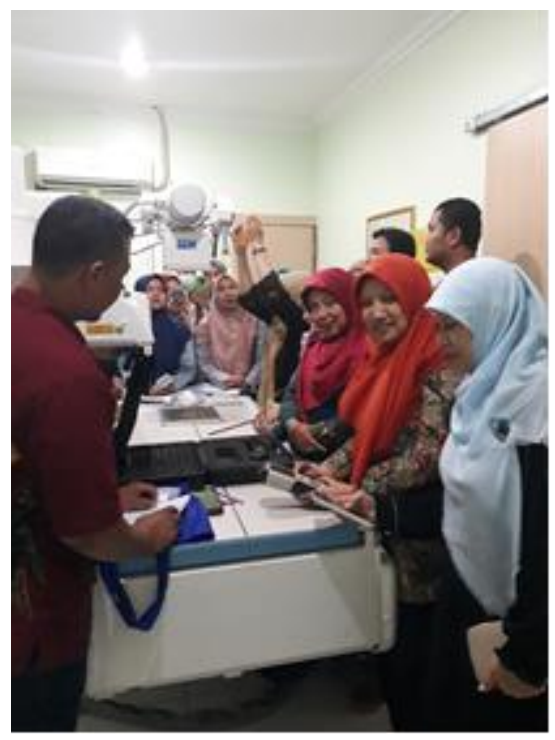

Gambar 2. Praktek di ruangan radiologi RS Roemani Muhammadiyah Semarang

Hands-On pengujian sistem kolimator sebagai upaya keselamatan radiasi pada unit pelayanan radiologi RS di Kota Semarang memiliki target Out-put berupa ketrampilan partisipan menerapkan dan melakukan prosedur pengujian sistem kolimator secara tepat; penyajian pelaporan dan menentukan tindak lanjut solusi pemecahan masalah. 
Masing-masing peserta pengabmas dapat mempraktekkan di tempat bekerjanya masingmasing baik di RS maupun di Klinik tempat mereka bekerja. Hasil pengujian kemudian dilaporkan kepada tim pengabmas berupa hasil rencana tindak lanjut dari program pengabmas.

Harapan tim pengabmas peserta dapat melakukan pengujian sistem kolimator di semua ruangan pemeriksaan yang ada di Rumah Sakit atau Klinik masing-masing dan melakukannya secara rutin serta berkesinambungan.

Dari pelaksanaan kegiatan sosialisasi dan pelatihan, serta evaluasi diperoleh umpan balik dari peserta. Peserta menyambut baik kegiatan pengujian sistem kolimator sebagai upaya keselamatan radiasi pada unit pelayanan radiologi Rumah Sakit/Lab Klinik di Kota Semarang, sehingga dapat menerapkannya di tempat kerja masing-masing. Diskusi dilakukan setelah selesai praktik di lab untuk mengetahui kendala yang mungkin terjadi saat pengukuran dan hasil dari pengujian sistem kolimator. Hal ini sangat penting karena kolimasi merupakan salah satu parameter utama yang secara langsung mempengaruhi dosis radiasi pasien dan menentukan kelayakan operasi pesawat sinar- $X$ tersebut harus diuji meliputi uji iluminasi lampu kolimator, selisih lapangan kolimasi dengan lapangan berkas sinat- $X$ dan ketegaklurusan berkas sinar-X (Badan and Tenaga 2014)

\section{Simpulan dan Saran}

Kegiatan Pengabmas yang berupa Hands-On pengujian dan evaluasi dari hasil pengujian sistem kolimator sebagai upaya keselamatan radiasi pada unit pelayanan radiologi RS di Kota Semarang, diawali dengan metode pemberian materi dan video, praktek pengujian, serta pendampingan di lapangan. Output dari pengabmas ini adalah adanya buku petunjuk praktek sistem kolimasi dan peningkatan pengetahuan serta keterampilan radiographer dalam pengujian kolimator di rumah sakit. Kegiatan ini menambah pengetahuan radiographer khususnya dalam pengujian secara sederhana sistem kolimator dengan peningkatan pengetahuan sebesar $84,79 \%$.

Adapun evaluasi kegiatan menyatakan bahwa 96, 7 \% kegiatan berguna di tempat kerja; posedur praktek 96,7 mudah dilakukan, 100\% menyatakan prosedur uji bisa diaplikasikan di radiologi masing-masing, 86,7 komitmen untuk melakukan di rumah sakit/klinik tempat kerja, $100 \%$ menyatakan kesediaan untuk dilakukan pendampingan.
Kegiatan serupa perlu dilakukan secara kontinyu untuk meningkatkan pengetahuan maupun wawasan bagi radiografer tentang prosedur pengujian dan evaluasi hasil pengujian kolimator agar keselamatan radiasi di unit Radiologi dapat tetap terjaga. Hal ini sangat penting dilakukan sebagai upaya pemenuhan data sebagai baseline kinerja pesawat khususnya kolimator di unit Radiologi rumah sakit/klinik.

\section{Ucapan Terima Kasih}

Kami sampaikan terima kasih kepada Direktur Poltekkes Semarang dan jajarannya yang telah memberikan kesempatan dalam mendapatkan dana Pengambas Poltekkes Kemenkes Semarang. PARI Pengcab kota Semarang atas fasilitas tempat praktek pengujian dan segenap peserta dari Rumah Sakit/kilinik yang terlibat pada pengabdian kepada masyarakat ini, kami juga mengucapkan terima kasih atas ijin dan kerjasamanya sehingga pengabmas ini dapat terlaksana dengan baik.

\section{Daftar Pustaka}

Badan, Kepala, and Pengawas Tenaga. 2014. "Perka Bapeten Nomor 15 Tahun 2014."

BAPETEN. 2018. “Perka Bapeten Nomor 2 Tahun 2018 Tentang Uji Kesesuaian Pesawat Sinar-X Radiologi Diagnostik Dan Intervensional." Nomor 2 Tahun 2018 Tentang Uji Kesesuaian Pesawat Sinar-X Radiologi Diagnostik Dan Intervensional.

Bushong, Stewart. 2016. Radiologic Science for Technologists, Physics, Biology, and Protection.

Carlton, R. R., \& Adler, A. M. K. 2013. “Principles of Radiographic Imaging: An Art and a Science." Clifton Park, NY: Delmar/Cengage Learning.

Dwi Rochmayanti, Tiara Pratiwi Putri, Sugeng Hariadi. 2017. "Analisis Pengujian Sistem Kolimasi Pesawat Mobile Unit Sinar-X Merk Toshiba DRX-1603B Di Instalasi Radiologi Rumah Sakit Umum R.A Kartini Jepara." Jurnal Radiografi Dan Imejing XIII.

Gammex. 2003. Quality Control for Diagnostic Radiology. Middleton WI USA.

Hotromasari, Dabukke. 2018. "Pengujian Iluminasi , Kolimasi , Ketegaklurusan Dan Kualitas Berkas Pesawat Sinar-X Radiografi Umum Dengan Radiografi 
Mobile." 78.

Kemenkes. 2009. “Keputusan Menteri Kesehatan No 1250 Tahun 2009 Tentang Kendali Mutu Radiodiagnostik."

Papp, J. 2015. Quality Management in the Imaging Sciences. St. Louis, Mo: Mosby.
Sari Ayu Wita, hartina siti. 2017. “Uji Kesesuaian Collimator Beam Dengan Berkas Sinar-x Pada Pesawat Raico Di Instalasi Radiologi Raden Mattaher Jambi." Batan 29-34. 